\title{
Farmers' Perceptions of Rice Production Constraints and Stem Borers Management Practices in Tanzania
}

\author{
Bonaventure January ${ }^{1,2}$, Gration M. Rwegasira ${ }^{1} \&$ Tadele Tefera $^{3}$ \\ ${ }^{1}$ Department of crop Science and Horticulture, Sokoine University of Agriculture, Morogoro, Tanzania \\ ${ }^{2}$ International Centre of Insect physiology and Ecology (ICIPE), Duduville Campus, Nairobi, Kenya \\ ${ }^{3}$ International Centre of Insect physiology and Ecology (ICIPE), ILRI Campus, Addis Ababa, Ethiopia \\ Correspondence: Bonaventure January, Department of crop Science and Horticulture, Sokoine University of \\ Agriculture, Morogoro, Tanzania. Tel: 255-759-900-645. E-mail: bojatetesha@gmail.com
}

Received: March 6, 2018

Accepted: April 6, $2018 \quad$ Online Published: May 15, 2018

doi:10.5539/jas.v10n6p57

URL: https://doi.org/10.5539/jas.v10n6p57

The research is financed by USAID Feed the Future IPM Innovation Lab, Virginia Tech, Cooperative [Grant No. AID-OAA-L-15-0000].

\begin{abstract}
Rice farmers in Tanzania continue to experience losses due to stem borers. However, the information on farmers' knowledge and perceptions of rice stem borers is limited and farmers' efforts on managing this insect have been ineffective. The aim of this study was to investigate constraints affecting rice production and farmers' approaches of stem borer management in irrigated low land rice ecosystems in Tanzania. Research method: A focus group discussion with farmers using a semi-structured questionnaire was used for data collection. The information collected included: farmers' socio-economic profiles, farm characteristics, knowledge and perceptions of stem borers and their management practices.Farmers reported insect pests such as stem borers, white flies, leaf rollers and grasshoppers as major constraints of rice production. Other constraints reported were such as diseases, damage by birds, drought, weeds and lack of access to credit for purchasing inputs. Most of the farmers apply chemical insecticides against rice insect pests particularly stem-borers where number of health hazards have been reported. Very few farmers use cultural methods including crop residue disposal and split application of nitrogenous fertilizers for reduction of stem borer damages. The study revealed that, most farmers have limited knowledge on the recommended stem borer management practices and suggests that environmentally friendly pest management methods to be designed and implemented to minimize losses associated with rice stem borers.
\end{abstract}

Keywords: farmers' perceptions, constraints, low land rice, management practices, stem borers, Tanzania

\section{Introduction}

Rice (Oryza sativa L.) is the dominant staple food in the developing world (Sarwar, 2012). Rice comes next to maize as most cereal food crop in Tanzania and it is grown in more than 10 regions (Mghase et al., 2010). However the yield is very low, 1-1.5 tons per hactre due to several constraints including insect pests (RLD, 2009). More than one hundred species of insects have been reported to attack rice crop among which are rice stem borers (Pathak, 1968). An estimated rice yield loss of about $10 \%$ is incurred by rice insect pests to resource-poor farmers in developing countries (Mati, 2009) and rice grain yield loss of up to $91 \%$ due to stem borers in neighbouring Kenya (Kega et al., 2016).

Rice stem borers have been reported as the most economically important insect pests of rice (Sigsgaard, 2000). There are about 20 stem borer species which have been reported worldwide as insect pests of rice with only four species reported in Africa as pests of economic importance. These include: Spotted stem borers (Chilo spp.), Stalk eyed fly (Diopsis longcornis Macquart), African white stem borer (Maliarpha separatalla Ragonot) and African Pink stem borer (Sesamia calamistis Hampson) (Ogah, 2013). Rice stem borer species in East Africa belongs to two orders namely, Diptera and Lepidoptera. The Diptera stem borers include only one species named D. thoracica whereas Lepidopteran stem borers include three main species; M. separatella, S. calamistis and Chilo partellus (spotted stem borers) (Srivastava et al., 2003). On average the stem borer species eggs lasts for 
15 days, larval stage for 40 days, pupa for 11 days and adults live for two to six days (Nwilene et al., 2008). In Tanzania, three Lepidopteran stem borers have been reported as pest of economic importance in rice which includes C. partellus, M. separatella and S. calamistis (Banwo et al., 2002; Leornard \& Rwegasira, 2015). Management of stem borers is an intelligent selection of management tactics by considering several factors such as economics, ecology and social factors (Korir et al., 2016).

Understanding farmers' perception of stem borer problem and management tactics prior to engaging in to any research on managing the pest was imperative. Engaging farmers at planning stage of research is important in ensuring the relevance of any research to them. For example, Farrington and Martin (2005) reported that, involvement of farmers in research studies increases the chances of success in generation of appropriate agricultural technology. Studies by Witcombe et al. (2015), and Sheikh et al. (2017) reported participatory plant breeding were shown to be an effective way of selecting locally adapted rice genotypes and for improving farmers' access to useful crop genetic diversity in Rwanda.

Farmer's perception and indigenous knowledge on pests' management have been reported to provide useful information to incorporate into scientific knowledge for management of pests of economic importance (Grace, 1990; Bentley \& Thiele, 1999). For example, Nyeko and Alubayo (2005) reported on termite management in Uganda, Tefera (2004) on sorghum stem borer management in Ethiopia, Oben et al. (2015) on maize stem borers management in Cameroon, Gadisa and Birhane (2015) on Rodents control in Ethiopia, and Materu et al. (2016) reported on management of tomato leaf miner in Tanzania.

Rice farmers in Tanzania continue to experience losses due to stem borers. However, the information on farmers' knowledge and perceptions of rice stem borers is limited and farmers' efforts on managing this insect have been ineffective. Understanding farmers' socio-economic factors, their knowledge, perceptions, and their current pest management practices are critical steps towards developing sustainable and cost effective integrated pest management (IPM) strategies (Alibu et al., 2016). The aim of this study was to determine farmers' perceptions of rice production constraints and stem borers management practices in irrigated lowland rice ecosystems in Tanzania.

\section{Materials and Methods}

\subsection{Description of the Study Sites}

Field surveys were conducted in three wards in Kilombero valley of Kilombero district, Morogoro Tanzania which are under irrigated rice ecosystem from December 2016 to January 2017. A total of six villages, two from each ward, were surveyed (Figure 1). The six villages covered by the study were Signali $\left(7^{\circ} 59^{\prime} 54.1115^{\prime \prime} \mathrm{S}\right.$, $36^{\circ} 50^{\prime} 7.0177^{\prime \prime}$ E, 271 m.a.s.l) and Sululu (7'59'45.8149" S, 36 50'7.7237" E, 268.81 m.a.s.l) in Signal ward; Mkula (746'4.2672" S, 36 56 $43.4076^{\prime \prime}$ E, 261.27 m.a.s.l) and Msufini $\left(7^{\circ} 47^{\prime} 30.125^{\prime \prime}\right.$ S, 36 $6^{\circ} 4^{\prime} 7.9283^{\prime \prime}$ E,

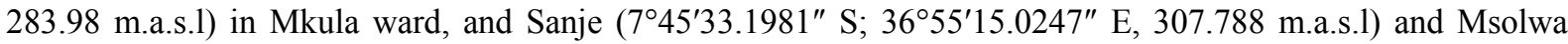
$\left(7^{\circ} 45^{\prime} 58.729^{\prime \prime}\right.$ S, 36 $54^{\prime} 58.9878^{\prime \prime}$ E, 289.03 m.a.s.l) in Sanje ward.

These wards represent irrigated low land rice ecosystem of Tanzania, where rice cultivation is constrained by rice stem borers. The three wards have total number of 942 household farms of rice which are under irrigation including, Signal (220), Mkula (294) and Sanje (428) (Mosha et al., 2016). Most villages in the district experience bimodal rainfall pattern characterized by two rainfall peaks in a year with a definite dry season separating the short and long rains. The short rain season is from October to December while the long rain season starts from March and ends in May (Msanya et al., 2003). Despite the bimodal occurrence of rains, rice is continuously grown under irrigation systems. 


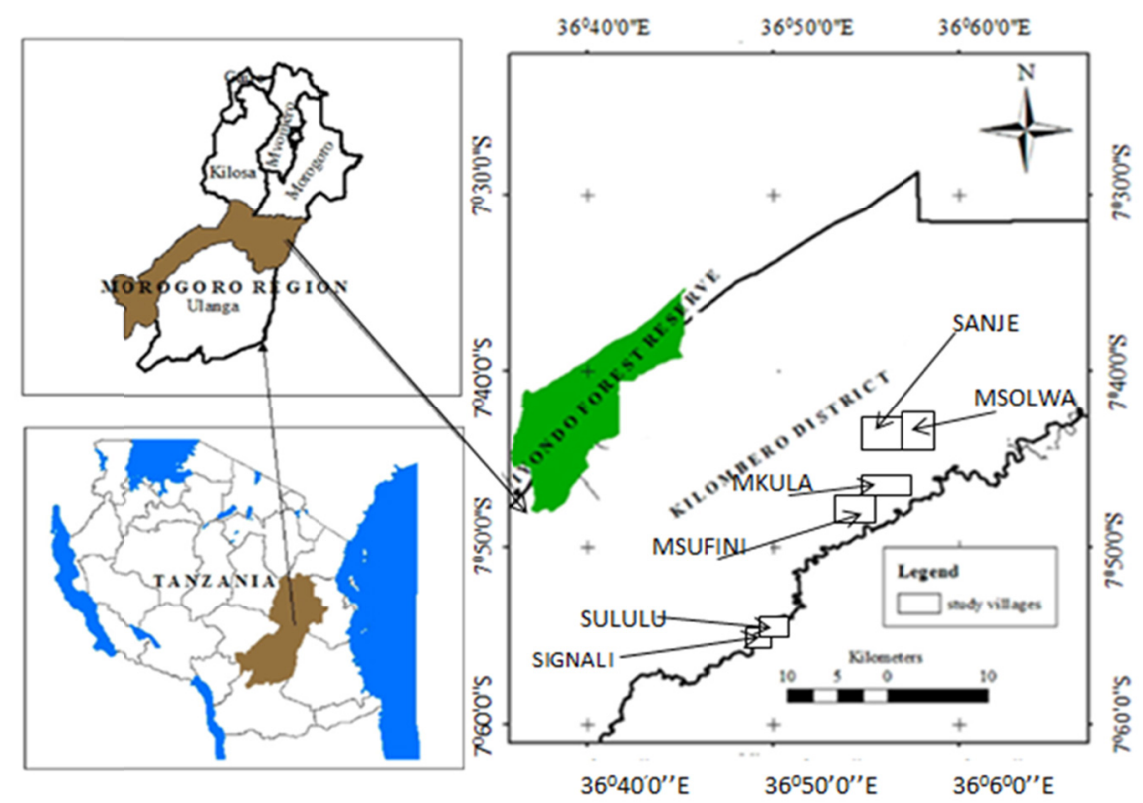

Figure 1. Map of Tanzania showing Morogoro region and location of study sites in Kilombero district by villages as indicated by arrows

\subsection{Sampling Procedure}

Multi-stage and cluster-sampling techniques were used to identify the village samples to ensure good representativeness of rice farming population in the study areas. In the first stage, three wards, namely, Sanje, Mkula and Signal were identified as among the key irrigated low land rice ecosystem in Kilombero Tanzania; thus, targeted for the study. At the ward level, two respective villages from each ward were purposively selected for sample household's survey. The villages were Sanje and Msolwa of Sanje ward, Mkula and Msufini of Mkula ward and Signal and Sululu of Signali ward. In each village 10 farmers were selected for face to face interview. The three wards and the two villages in Kilombero district were selected because of their intensive rice cultivation due to availability of enough water for irrigation throughout the year. The sample size $(\mathrm{N})$ was determined by using Equation as described by T. H. Wonnacott and R. J. Wonnacott (1990) attest as follows:

$$
\mathrm{N}=\mathrm{Z}^{2} \cdot \mathrm{P}(1-\mathrm{P}) / \mathrm{Q}^{2}
$$

Where, $\mathrm{N}=$ required sample size, $\mathrm{Z}=$ confidence level at $95 \%$ (standard value of 1.96 ), $\mathrm{p}=$ estimated proportion of an attribute, which was estimated at $90 \%$ (standard value of 0.9 ) due to the fact that about $90 \%$ of the rural population in Tanzania are employed in farming activities (Mlambiti, 1998) and $\mathrm{Q}=$ margin of error at $5 \%$ (standard value of 0.05). Therefore, using Equation above $\mathrm{N}$ was determined.

The sample size of 138.3, approximated to 140 households was equally distributed between Sanje, Msolwa, Mkula, Msufini, Signali and Sululu villages accounting for twenty-four (24) farming households in each village. Due to time constraint and poor road network, a target of twenty (20) households (representing $83.33 \%$ of village sampled population) was expected to participate in the formal interview. Ultimately, 10 respondents from each village making a total of sixty (60) households were recorded (representing a response rate of $41.67 \%$ ) which was satisfactory for this study. This number was in line with the study of Saunders et al. (2007) who argued that a sample size of 30 or more will result into sampling distribution which is very closer to the normal distribution. The selection of farmers was done in collaboration with village leaders and agricultural extension officers taking into consideration the gender, age of farmer, education, farm size and income.

\subsection{Data Collection and Analysis}

A semi-structured questionnaire (Appendix 1) was administrated by trained agricultural enumerators after pre-testing the questionnaire for its validity. The information collected included: farmers' socio-economic profiles, farm characteristics, knowledge and perceptions of stem borers and their management practices. Farmers were interviewed in their local language (Kiswahili) at their home for 40-45 min. The questionnaires were discussed during face-to-face interviews with individual farmers and addressed information on farmers' socio-economic profile (e.g. age, gender, education, and family size), farm size, rice production constraints. 
Quantitative and qualitative data collected through the questionnaire were coded and subjected to statistical analyses using the Statistical Package for Social Sciences software (SPSS Inc., 2005). Cross-tabulations tables were constructed and descriptive statistics were calculated to summarize data from the questionnaires. To make statistical inferences, contingency chi-square tests were computed at a given level of significance to analyse relationships between variables. This allowed empirical analyses and description of associations between the collected parameters across the six study villages.

\section{Results}

\subsection{Basic Information of the Households}

Rice farming system under study area is represented by smallholder farmers with an average land size ranging from less than 1-3 acres with very few farmers owning more than 3 acres (Table 1). The proportion of male-headed (61.67\%) households was higher than females-headed $(38.33 \%)$. About $35 \%$ of the farmers interviewed were aged between 36-45 years and about 50\% of the respondents had family size of four to six individuals. Most farmers (71.67\%) were able to read and write in local language (Kiswahili), 21.67\% in Kiswahili and English languages, while $6.67 \%$ were unable to read and write. About $70 \%$ the farmers income was through rice farming with an average grain yield of $4949.38 \mathrm{~kg}$ per ha (Table 1) whilst $71.6 \%$ of the yield was used for home consumption and $28.3 \%$ was sold (Figure 2).

Table 1. Demographic and social economic information of the households in study sites (\%)

\begin{tabular}{|c|c|c|c|c|c|c|c|c|}
\hline \multirow{2}{*}{ Variable } & \multirow{2}{*}{ Class } & \multicolumn{6}{|c|}{ Villages } & \multirow{2}{*}{ Mean } \\
\hline & & Sululu & Signali & Mkula & Msufini & Sanje & Msolwa & \\
\hline \multirow[t]{2}{*}{ Gender } & Male & 80 & 40 & 60 & 60 & 80 & 50 & 61.7 \\
\hline & Female & 20 & 60 & 40 & 40 & 20 & 50 & 38.3 \\
\hline \multirow[t]{4}{*}{ Age (years) } & $18-35$ & 20 & 30 & 50 & 30 & 20 & 10 & 26.7 \\
\hline & $36-45$ & 40 & 40 & 40 & 40 & 30 & 20 & 35.0 \\
\hline & $46-60$ & 30 & 30 & 10 & 30 & 30 & 40 & 28.3 \\
\hline & $61-80$ & 10 & 0 & 0 & 0 & 20 & 30 & 10.0 \\
\hline \multirow[t]{4}{*}{ Family size } & $\leq 3$ & 40 & 10 & 50 & 0 & 10 & 30 & 23.3 \\
\hline & $4-6$ & 60 & 60 & 30 & 60 & 50 & 40 & 50.0 \\
\hline & $7-10$ & 0 & 20 & 20 & 40 & 20 & 20 & 20.0 \\
\hline & $>10$ & 0 & 10 & 0 & 0 & 20 & 10 & 6.7 \\
\hline \multirow[t]{3}{*}{ Education level } & Primary & 90 & 10 & 90 & 90 & 70 & 80 & 71.7 \\
\hline & Secondary & 10 & 90 & 10 & 10 & 10 & 0 & 21.7 \\
\hline & Illiterate & 0 & 0 & 0 & 0 & 20 & 20 & 6.7 \\
\hline \multirow[t]{3}{*}{ Size of rice field (acres) } & $\leq 1$ & 10 & 0 & 30 & 20 & 30 & 20 & 18.3 \\
\hline & $2-3$ & 90 & 100 & 70 & 70 & 70 & 60 & 76.7 \\
\hline & $>3$ & 0 & 0 & 0 & 10 & 0 & 20 & 5.0 \\
\hline \multirow{2}{*}{$\begin{array}{l}\text { Proportion of farmer' income } \\
\text { which is from rice }\end{array}$} & $<0.5$ & 50 & 20 & 10 & 10 & 30 & 60 & 30.0 \\
\hline & $>0.5$ & 50 & 80 & 90 & 90 & 70 & 40 & 70.0 \\
\hline Yield $(\mathrm{Kg} / \mathrm{ha})$ in 2016 & & 4388 & 5873 & 3709 & 6120 & 6023 & 3585 & 4949 \\
\hline
\end{tabular}

Note. Number of respondents $(\mathrm{N})=60$. 


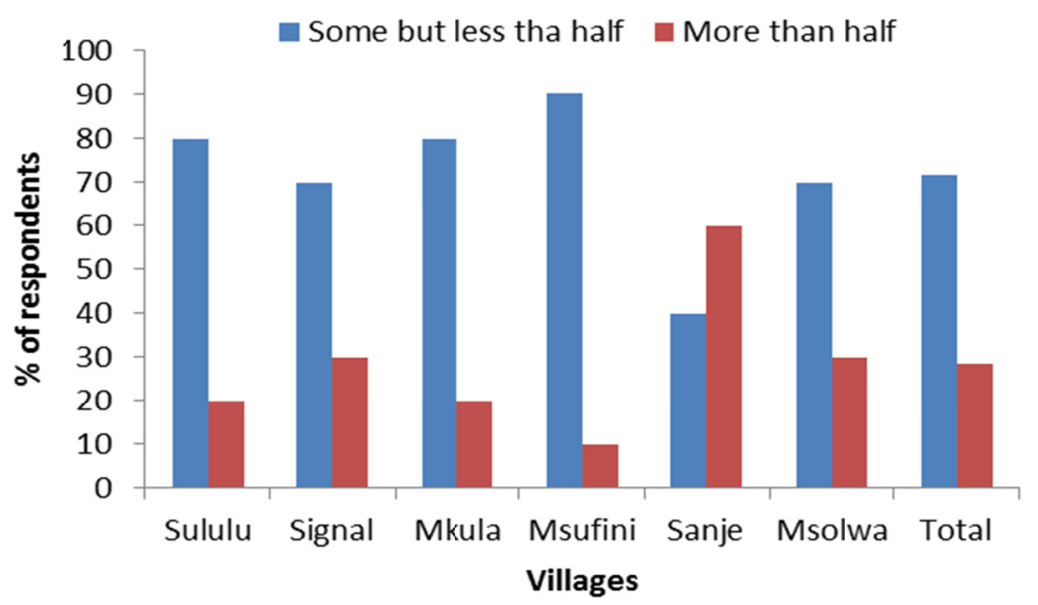

Figure 2. Response of farmers on the percentage of rice yield which are for home consumption

\subsection{Awareness of Farmers on Rice Stem Borers in Relation to Gender}

During survey both male and women farmers were asked whether they know rice stem borers. About $35 \%$ of women out of all individuals interviewed were aware whereas only $3.3 \%$ were unaware on stem borer problem. On the other hand, about $56.6 \%$ of men out of all individuals interviewed were aware whereas only $5 \%$ were unaware on rice stem borer problem (Table 2). The influence of gender on awareness of rice stem borers problem was not significantly different among men and women $\left(X^{2}=0.06 ; P=0.936\right)$ (Table 2$)$.

Table 2. Influence of gender on farmer's awareness on rice stem-borers (\%)

\begin{tabular}{lllllll}
\hline Gender & Aware & Unaware & Total & Chi-square & df & P-value \\
\hline Women & 35.00 & 3.33 & 38.3 & 0.06 & 1 & 0.936 \\
Men & 56.66 & 5.00 & 61.7 & & & \\
Total & 91.66 & 8.33 & 100.0 & & & \\
\hline
\end{tabular}

Note. $\mathrm{df}=$ degrees of freedom, Number of respondents $(\mathrm{N})=60$.

\subsection{Effect of Farmer's Age on Stem Borer Management}

The relationship between different age groups of respondents and stem borer management options are presented in Table 3. In the age group of $\leq 35$ years, $5 \%$ of farmers manage stem borers through burning of crop residues, $1.67 \%$ remove and burry infested plants, $18.5 \%$ use insecticides and $1.67 \%$ does not use any management option. In the age group of $36-45$, about $6.7 \%$ of respondents burn crop residues, $25 \%$ use insecticides, $1.67 \%$ use split application of Nitrogen fertilizer and $1.67 \%$ does not using any management option. Another age group was that of 46-60 years where $1.67 \%$ of respondents reported to manage stem borers through removal and burry infested plants and $26.6 \%$ use insecticides. The last age group was that $>60$ years whereby $1.67 \%$ reported to manage stem borers through burning of crop residues and $8.33 \%$ use insecticides stem borer management options were not influenced by the age groups $\left(X^{2}=8.85 ; p=0.715\right)$. 
Table 3. Effect of farmer's age and education level on stem borer management options

\begin{tabular}{|c|c|c|c|c|c|c|c|c|c|c|}
\hline \multirow[b]{2}{*}{ Variable } & \multirow[b]{2}{*}{ Class } & \multicolumn{9}{|c|}{ Stem borer management options } \\
\hline & & $\begin{array}{l}\text { Burning } \\
\text { of Crop } \\
\text { residues }\end{array}$ & $\begin{array}{l}\text { Remove } \\
\text { and burry } \\
\text { Infested } \\
\text { plants }\end{array}$ & $\begin{array}{l}\text { Use of } \\
\text { Insecticides }\end{array}$ & $\begin{array}{l}\text { Split } \\
\text { application } \\
\text { of } \mathrm{N} \text {-fertilizer }\end{array}$ & $\begin{array}{l}\text { Not using any } \\
\text { management } \\
\text { option }\end{array}$ & Total & Chi-square & df & P-value \\
\hline \multirow[t]{5}{*}{ Age (years) } & $18-35$ & 5 & 1.67 & 18.35 & 0 & 1.67 & 26.7 & 8.85 & 12 & 0.715 \\
\hline & $36-45$ & 6.7 & 0 & 25 & 1.67 & 1.67 & 35 & & & \\
\hline & $46-60$ & 0 & 1.67 & 26.6 & 0 & 0 & 28.3 & & & \\
\hline & $61-80$ & 1.67 & 0 & 8.33 & 0 & 0 & 10 & & & \\
\hline & $>10$ & 13.37 & 3.34 & 78.28 & 1.67 & 3.34 & 100 & & & \\
\hline \multirow[t]{3}{*}{ Education level } & Primary & 0 & 1.7 & 3.3 & 0 & 0 & 5 & 12.99 & 8 & 0.112 \\
\hline & Secondary & 11.7 & 1.7 & 68.3 & 1.7 & 1.7 & 85 & & & \\
\hline & Illitrates & 1.7 & 0 & 6.6 & 0 & 1.7 & 10 & & & \\
\hline Total & & 13.3 & 3.3 & 78.3 & 1.7 & 3.3 & 100 & & & \\
\hline
\end{tabular}

Note. $\mathrm{df}=$ degrees of freedom, Number of respondents $(\mathrm{N})=60$.

\subsection{Effect of Education Levels on Management of Stem Borers}

The relationship between different education level groups of respondents and stem borer management options are presented in Table 3 . About $1.66 \%$ of illiterate farmers manage insect pests by removal and burying infested plants and 3.3\% use insecticides. About $11.67 \%$ of farmers with standard seven level of education manage insect pests through burning of crop residues after harvest, $1.67 \%$ remove and burry infested plants, $68.33 \%$ use insecticides, $1.67 \%$ use split application of Nitrogenous fertilizer and 1.67 do not use any control measure. The last education group of farmers are those who attended secondary school to form four levels where about $1.67 \%$ manage stem borers through burning of crop residues, $6.67 \%$ using insecticides and 1.67 do not use any control measure. The results indicated that the stem borer management options are not influenced by education level $\left(X^{2}\right.$ $=12.99 ; p=0.112$.

\subsection{Constraints to Rice Production}

Most farmers, $96.76 \%$, reported insect pests such as stem borers, white flies, leaf rollers and grasshoppers as major constraints to rice production (Figure 3). Other constraints reported were such as diseases (36.66\%), damage by birds $(98.3 \%)$, drought (33.33\%), weeds (78.33\%) and lack of access to loan for purchasing inputs such as improved seeds, fertilizers, insecticides and herbicides (75\%). The responses of yes to all production constrains by farmers didi not differed significantly among the villages except for weeds, diseases and drought $(P<0.05)$.

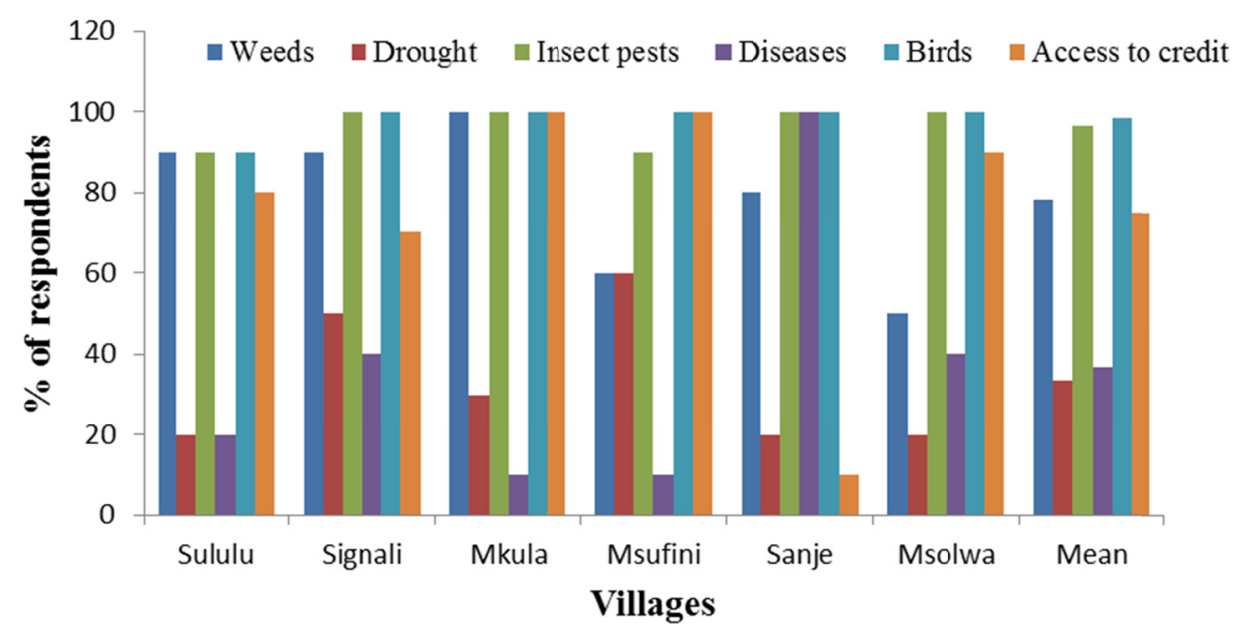

Figure 3. Percentage of farmers who responded yes to the variables (weeds, drought, insect pests, diseases, birds and access to credit as production constraints in different villages 


\subsection{Farmers's Perception on Infestation by Rice Stem Borers Among Other Insect Pests}

Rice stem borers were reported by $56.7 \%$ of respondents as the most serious insect whereas $40 \%$ farmers reported white flies as the most serious insect pest. Only $1.7 \%$ the farmers reported other insects as serious pest (Figure 4). Among the farmers interviewed, $40 \%$ reported the severity of stem borers from previous year was high, 55\% medium, and 5\% low with no significant differences within villages $\left(X^{2}=14.8 ; p=0.141\right)$ (Table 4$)$.

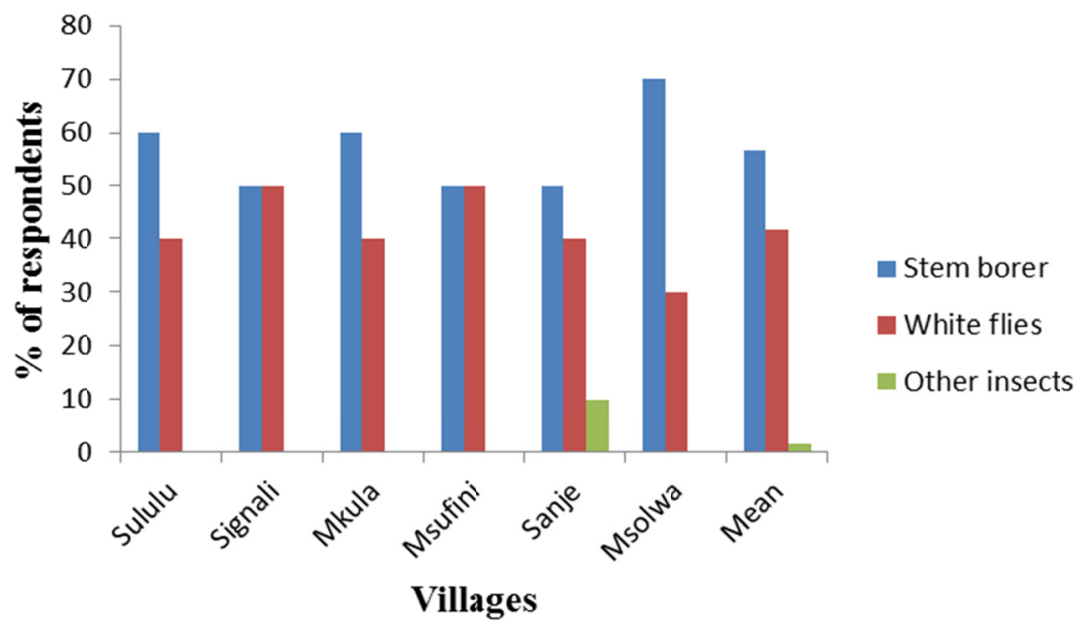

Figure 4. Percentage of responses from respondents on which insect pest was worst in previous season in different villages

Table 4. Farmer's perception on rice stems borer's infestation (\%)

\begin{tabular}{|c|c|c|c|c|c|c|c|c|c|c|}
\hline \multirow{2}{*}{ Stem borer Infestation level } & \multicolumn{6}{|c|}{ Villages } & \multirow{2}{*}{ - Mean } & \multirow{2}{*}{ Chi-square } & \multirow{2}{*}{$\mathrm{df}$} & \multirow{2}{*}{ p-value } \\
\hline & Sululu & Signali & Mkula & Msufini & Sanje & Msolwa & & & & \\
\hline Low & 0 & 0 & 10 & 0 & 0 & 0 & 5.0 & 14.8 & 10 & 0.141 \\
\hline Medium & 80 & 80 & 40 & 60 & 40 & 30 & 55.0 & & & \\
\hline High & 20 & 20 & 50 & 40 & 60 & 50 & 40.0 & & & \\
\hline
\end{tabular}

Note. $\mathrm{df}=$ degrees of freedom, $\mathrm{N}=60$.

\subsection{Farmer-Based Management Options for Rice Stem Borers}

Most farmers (78.33\%) used chemical insecticides for rice insect pests' management, $13 \%$ burnt crop residues, $3.33 \%$ removed and buried infested plants and $1.7 \%$ used balanced Nitrogen fertilizers. About $65 \%$ of the farmers reported the use of insecticides, $20 \%$ uprooting and burning of infested plants and $6.7 \%$ used split application of Nitrogen fertilizer as common practices they use to reduce stem borers infestation in rice (Table $5)$.

Table 5. Farmer based management options for rice stem borers (\%)

\begin{tabular}{|c|c|c|c|c|c|c|c|c|c|c|}
\hline \multirow{2}{*}{ Control strategy } & \multicolumn{6}{|c|}{ Village of the respondent } & \multirow{2}{*}{-Mean } & \multirow{2}{*}{ Chi-square } & \multirow{2}{*}{ df } & \multirow{2}{*}{ p-value } \\
\hline & Sululu & Signali & Mkula & Msufini & Sanje & Msolwa & & & & \\
\hline Burning infested straw and stubble & 20 & 10 & 30 & 40 & 20 & 0 & 20 & 15.49 & 15 & 0.417 \\
\hline Use of insecticides & 70 & 80 & 70 & 30 & 6 & 80 & 65 & & & \\
\hline Split application of $\mathrm{N}$ fertilizer & 10 & 10 & 0 & 10 & 10 & 0 & 6.7 & & & \\
\hline Not using any strategy & 0 & 0 & 0 & 20 & 10 & 20 & 8.3 & & & \\
\hline
\end{tabular}

Note. $\mathrm{df}=$ degrees of freedom. 


\subsection{Chemical Inputs Used by Rice Farmers for Management of Stem Borers}

The insecticides used by rice farmers were Kung'fu, Karate and Atakan which are having the same active ingredient called lambda cyhalothrin (Table 6). About $26.67 \%$ of respondents were using Kung'fu, $25 \%$ Karate and 16.67 Atakan; however, $31.67 \%$ were not using any insecticide. About $56.6 \%$ farmers reported to use Urea and DAP, $20 \%$ reported Urea and minjingu phosphate rock, $10 \%$ reported Urea only and $10 \%$ reported DAP only. Very few farmers (3.3\%) were not applying fertilizers to rice (Table 6).

Table 6. Chemical inputs used by farmers (\%)

\begin{tabular}{lllllllll}
\hline \multirow{2}{*}{ Inputs used } & \multirow{2}{*}{ Input type } & \multicolumn{5}{c}{ Villages of respondents } \\
\cline { 3 - 7 } & & Sululu & Signali & Mkula & Msufini & Sanje & Msolwa & \\
\hline Insecticides & Kung'fu & 20 & 30 & 20 & 10 & 40 & 40 & 26.7 \\
& Karate & 50 & 20 & 20 & 10 & 20 & 30 & 25.0 \\
& Atakan & 20 & 30 & 30 & 10 & 10 & 10 & 16.7 \\
\cline { 2 - 7 } Fertilizers & Not using any insecticide & 20 & 20 & 30 & 70 & 30 & 20 & 31.7 \\
& Using Urea & 0 & 0 & 30 & 10 & 20 & 0 & 10.0 \\
& Using DAP & 20 & 0 & 10 & 3 & 0 & 0 & 10.0 \\
& Using DAP and Urea & 50 & 100 & 60 & 50 & 20 & 60 & 56.7 \\
& Using Urea and Minjingu phosphate & 30 & 0 & 0 & 0 & 50 & 40 & 20.0 \\
& Not using any fertilizer & 0 & 0 & 0 & 10 & 10 & 0 & 3.3 \\
\hline
\end{tabular}

Note. DAP $=$ Di-Ammonium Phosphate.

\subsection{Rice Growing Season and Stem Borer's Damage}

About $40 \%$ farmers mentioned severity of rice stem borers during dry season while $20 \%$ reported the pest as a problem in wet season (Table 7).

Table 7. Response of farmers on rice cropping season where stem borers are more severe (\%)

\begin{tabular}{|c|c|c|c|c|c|c|c|c|c|c|}
\hline \multirow{2}{*}{ Season } & \multicolumn{6}{|c|}{ Village of the respondent } & \multirow{2}{*}{ Mean } & \multirow{2}{*}{ Chi-square } & \multirow{2}{*}{ df } & \multirow{2}{*}{ P-value } \\
\hline & Sululu & Signali & Mkula & Msufini & Sanje & Msolwa & & & & \\
\hline Wet season & 20 & 10 & 30 & 20 & 30 & 10 & 20 & 8.5 & 15 & 0.902 \\
\hline Dry season & 40 & 30 & 40 & 40 & 40 & 50 & 40 & & & \\
\hline Both wet and dry season & 10 & 30 & 20 & 10 & 10 & 0 & 13 & & & \\
\hline Not known & 30 & 30 & 10 & 30 & 20 & 40 & 26.7 & & & \\
\hline
\end{tabular}

Note. $\mathrm{df}=$ degrees of freedom, Number of respondents $(\mathrm{N})=60$.

\section{Discussions}

Rice cultivation under the study area was represented by small scale farmers the majority of whom were males with very small piece of land which are all under irrigation system. All individuals interviewed were older than 18 years which is essential group for decision making power on the crop and variety to grow, the size of land to cultivate and the date of planting, which in turn have an impact in rice production (Mrema et al., 2015). Most farmers under the study area have either attended primary school or illiterate with very a small number that attended secondary schools to form four levels. This suggests that service providers must communicate orally during services. The few educated individual farmers could act as facilitators alleviating constraints and identifying needs and priorities of none educated farmers and enhance adoption of any new technologies of rice cultivation in the study area.

Most farmers could not delineate whether rice production constraints existed or not. Lack to clear separation between the existence and non-existence of production constraints was attributed to similarity in soil characteristics, rainfall distribution, cropping system and pest management practices of the farmers under the study area. All these factors influence insect pests' infestation to the rice crop. Such environmental conditions agree with the observation of Hossain et al. (2013) who reported that the low yield of rice in Bangladesh was contributed to soil fertility status, rainfall distribution pattern, cropping system and management practices of 
insect pests. The importance of these insects as most constraints may also be due to mono-cropping type of cultivation that farmers are undertaken due to the nature of the land. When only one crop is grown continuously in one area, will ensures food is available to stem borers throughout the year for them to survive and multiply.

Most farmers interviewed indicated medium to high severity of insect pest infestation in the year 2016 with stem borers being the most severe insect among the insects mentioned. This is attributed to the fact that most of farmers under the irrigation scheme in the study area planted rice crop in the same planting dates in that year that may have influence in rice insect pest infestation. This concurs with the study of Sarwar (2012) who reported that planting dates showed impact on the incidence of stem borers by which early planted rice crop was the most resistant having the lowest borer infestation among other plantings. Further Kfir et al. (2002) reported that crops grown at the period of least abundance of the pest ensures no interference between most susceptible stage of crop growth and the period of peak stem borer activity.

Stem borer management practices including use of insecticides, uprooting and burning of infested plants and split application of Nitrogen fertilizer were reported to be used by farmers during the survey under the study area thereby insecticides being used by most of farmers. The stem borer management options were neither influenced by gender nor education level. This was because most of farmers were of the same and of low education level (primary education) with little knowledge on selection of best and proper pest management options. Management of insect pests using chemical insecticides particularly in rice crop are still effective method (Sigh et al., 2015) but indiscriminate use can result in disruption of environment by accumulating the residues to the harvested produce which are not safe to human health. The chemical insecticides can also affect non-target organisms such as natural enemies which are user friendly to farmers by reducing their numbers (Preetha et al., 2009; Sigh et al., 2015).

Several fertilizers such as UREA, DAP and Minjingu rock phosphate were reported by the respondents during survey as being used in rice crop for the purpose of increasing yield and/or reducing insect pest infestation. Nitrogenous fertilizer such as UREA and DAP has direct influence on the vigour and increase of the tenderness of rice crop (Mgoo et al., 2005). These in some ways promote damages by stem borers especially when not used properly. The effect of fertilizer inputs has also described by Sarwar (2011) who reported how important is the plant nutrient in changing population dynamics of herbivores apart from being a good indicator in improving host plant quality. This was further supported by the study by Ogah et al. (2005) who reported increased rice gall midge damages in Nitrogen applied plots as compared to the control.

During the survey, it was also indicated that the stem borer's infestation in previous year was more severe during dry season than wet season. Mgoo et al. (2005) reported high abundance of maize stem borers during short rain season than in long rain season. Kega et al. (2017) reported that pest densities were found to be high in off season than rain season planted rice due to repetition of rice cultivation that favours population build-up of vegetative rice pests. In addition, continuous cultivation of rice under irrigated lowland rice ecosystem could favour the abundance of diverse vegetation which act as alternative host to pests. In line with the findings of the current study, Mailafiya et al. (2011) reported numerous wild host plants like Cyperus spp., Panicum spp., Pennisetum spp. and Sorghum spp. which are also found in the study area suggesting their potentiality as hosts of rice stem borers whenever is found. Continuation of stem borers breeding cycle may be another reason for high stem borer infestation reports during dry season than wet season in the study area. In contrary, during dry season stem borers tends to undergo resting period (diapause) due to insufficient food materials (Pathak \& Khan, 1994). This usually happened only under rain fed ecosystem where the crop is cultivated only once per year, unlikely under the study area where the crop is cultivated twice or thrice ensures continuous breeding cycle due to availability of host plant for feeding hence more infestation.

Change of environmental conditions can also be the cause of high stem borer infestation during dry season as reported by farmers in the current study. This is supported by the report of Khaliq et al. (2014) that distribution, development, survival, behaviour, migration, reproduction and population dynamics of insect pests of rice are affected by change of climatic factors such as temperature, relative humidity, rainfall and mass air movements. On the other hand, the high infestation of stem borers in dry season was contributed by continuous cultivation of rice under irrigation system that ensures continued availability of rice, the suitable host for the pest. Similar observation was reported by Hong-xing et al. (2017) who reported that intensive rice cultivation was the cause of increased stem borer's infestation levels.

\section{Conclussions}

Farmers are key stake holders and good sources of information in research studies, therefore need to be involved at the beginning of any study plan. They are so important due to their direct association with the crop which 
provided the chance to observe any damages that may be associated with insect pests. New innovations designed to control stem borers in rice under subsistence farming in Africa should consider farmers' knowledge of the pest, socioeconomic circumstances and current pest management practices.

\section{Acknowledgements}

This study was made possible through support provided by the Feed the Future Collaborative Research on Integrated Pest Management Innovation Lab of the US Agency for International Development, under the terms of grant No. AID-OAA-L-15-00001. The authors are grateful to the farmers and agriculture extension staff in Tanzania who participated in this study.

\section{References}

Alibu, S., Otim, M. H., Okello, S. E. A., Lamo, J., Ekobu, M., \& Asea, G. (2016). Farmer's knowledge and perceptions on rice insect pests and their management in Uganda. Journal of Agriculture, 6(3), 38. https://doi.org/10.3390/agriculture6030038

Banwo, O. O. (2002). Management of major insect pests of rice in Tanzania. Plant Protection Science, 38 , 108-113. https://doi.org/10.17221/4860-PPS

Bentley, J. W., \& Thiele, G. (1999). Farmer knowledge and management of crop disease. Journal of Agriculture and Human Value, 16, 75-81. https://doi.org/10.1023/A:1007558919244

Gadisa, T., \& Birhane, A. (2015). Farmers' perceptions of rodents as crop pests: Knowledge, attitude and practices of farmers about rodent pest nagement in Southwest Ethiopia. Journal of Agricultural Extension and Rural Development, 8(3), 39-46. https://doi.org/10.5897/JAERD2015.0739

Grace, J. Y. (1990). Public perception of termite control practices in several Ontario (Canada) Municipalities. Journal of Environmental Management, 30, 131-138. https://doi.org/10.1016/0301-4797(90)90010-T

Hong-xing, X., Ya-juna, Y., Yan-huia, L., Xu-songa, Z., Jun-cea, T., Feng-xiang, L., ... Zhong-xian, L. (2017). Sustainable management of rice insect pests by non-chemical-insecticide technologies in China. Rice Science, 24, 61-72. https://doi.org/10.1016/j.rsci.2017.01.001

Hossain, M. K., Kamil, A. P., Masron, T. A., \& Baten, M. A. (2013). Impact Environmental factors on efficience of rice production in Bangladesh. Journal of Applied Science, 3(4), 564-571. https://doi.org/10.3923/ jas.2013.564.571

Kega, V. M., Kasina, M., Olubayo, F., \& Nderitu, J. H. (2016). Assessment of yield loss caused by African White Rice Stem Borer (Maliarpha separatella Rag.) (Lepidoptera: Pyralidae) at Mwea Irrigation Scheme, Kirinyaga County, Kenya. Journal of Entomology, 13, 19-25. https://doi.org/10.3923/je.2016.19.25

Kega, V. M., Kasina, M., Olubayo, F., \& Nderitu, J. H. (2017). A Study of the African White Rice Stem Borer (Maliarpha separatella Rag.) Population Density Fluctuations at Mwea Irrigation Scheme in Central Kenya. Universal Journal of Agricultural Research, 5(1), 52-56. https://doi.org/10.13189/ujar.2017.050108

Kfir, R., Overholt, W. A., Khan, Z. R., \& Polaszek, A. (2002). Biology and management of economically important Lepidopteran cereal stem borers in Africa. Annual Review of Entomology, 47, 701-31. https://doi.org/10.1146/annurev.ento.47.091201.145254

Khaliq, A., Javed, M., Sohail, M., \& Sagheer, M. (2014). Environmental effects on insects and their population dynamics. Journal of Entomology and Zoology Studies, 2, 1-7. Retrieved October 20, 2017, from http://www.entomoljournal.com/vol2Issue2/pdf/32old.1.pdf

Korir, J., Muricho, G., \& Kassie, M. (2016). Kassie Farmers' Perceptions of Maize Stem Borer and Adoption of integrated pest management practices in Nakuru and Bomet Counties, Kenya. Rice, Maize and Chickpea IPM for East Africa Project (Working Document Series 4, p. 15). Retrieved from https://ipmil.oired.vt.edu/ wp-content/.../10/Maize_KAP-paper_12042017-final.pdf

Leonard, A., \& Rwegasira, G. M. (2015). Abundance and Spatial Dispersion of Rice Stem Borer Species in Kahama, Tanzania. Journal of Insect Science, 15(1), 132. https://doi.org/10.1093/jisesa/iev106

Mailafiya, D. M., Le Ru, B. P., Kairu, E. W., Dupas, S., \& Calatayud, P. A. (2011). Parasitism of lepidopterous stem borers in cultivated and natural habitats. Journal of Insect Science, 11(15), 1-19. https://doi.org/ $10.1673 / 031.011 .0115$

Materu, C. L., Shao, E. A., Losujaki, E., Chidege, M., \& Mwambela, N. (2015). Farmer's Perception Knowledge and Practices on Management of Tuta Absoluta Meyerick (Lepidotera Gelechiidae) in Tomato Growing 
Areas in Tanzania. International Journal of Research Agriculture and Forestry, 3(2), 1-5. Retrieved from http://www.ijraf.org/pdf/v3-i2/1.pdf

Mati, B. M. (2009). System of Rice Intensification; growing more with less water promoting the adoption of SRI in Kenya. IMAWESA Brief Notes (p. 6).

Mghase, J., Shiwachi, H., Nakasone, K., \& Takahashi, H. (2010). Agronomic and socio-economic constraints to high yield of upland rice in Tanzania. African Journal of Agricultural Research, 5(2), 150-158. https://doi.org/10.5897/AJAR09.459

Mgoo, V. H., Makundi, R. H., Pallangyo, B., Schulthess, F., Jiang, N., \& Omwega, C. (2006). Yield loss due to the stemborer Chilo partellus (Swinhoe) (Lepidoptera: Crambidae) at different nitrogen application rates to maize. Annals Society Entomology of France, 42, 3-4. https://doi.org/10.1080/00379271.2006.10697483

Mlambiti, M. E. (1998). Introduction to Rural Economy for East African Students (p. 165). Mzumbe Book Project, Morogoro, Tanzania.

Morris, M. L., \& Bellon, M. R. (2004). Participatory plant breeding research: Opportunities and challenges for the international crop improvement systems. Euphatica, 136, 21-55. https://doi.org/10.1023/B:EUPH.00000 19509.37769.b1

Mosha, D. B., Kajembe, G. C., Tarimo, A. K. P., \& Mbeyale, G. E. (2016). Perfomance of Water management Institutions in Farmer-managed Irrigation Schemes in Irringa Rural and Kilombero Districts. International Journal of Asian Social Science, 6(8), 430-445. https://doi.org/10.18488/journal.1/2016.6.8/1.8.430.445

Mrema, E., Shimelis, H., Laing, M., \& Bucheyeki, T. (2016). Farmers' perceptions of sorghum production constraints and Striga control practices in semi-arid areas of Tanzania. International Journal of Pest Management, 63(2), 146-156. https://doi.org/10.1080/09670874.2016.1238115

Msanya, B. M., Kaaya, K. A., Araki, S., Otsuka, H., \& Nyadzi, I. G. (2003). Pedological characteristics, general fertility and classification of some benchmark soils of Morogoro, Tanzania. African Journal of Science and Technology, 4(2), 101-112. http://doi.org/10.4314/ajst.v4i2.15309

Nwilene, F. E., Sanyang, S., Trao, A. K., Togola, A., Goergen, G., \& Agunbiade, T. A. (2008). Rice Stem Borers: Biology, Ecology and Control. Field Guide and Technical Manual (p. 28). Cotonou, Benin: Africa Rice Centre (Warda).

Nyeko, P., \& Alubayo, F. M. (2005). Participatory assessment of farmers experience of termite problem in agroforestry on Tororo district, Uganda (News Letter No. 143). Agricultural Research and Extension Network.

Oben, E. O., Ntonifor, N. N., Kekeunou, S., \& Abbevtakor, N. M. (2015). Farmers knowledge and perception on maize stem borers and their indigenous control methods in south western region of Cameroon. Journal of Ethnobiology and Ethnomedicine, 11, 77. https://doi.org/10.1186/s13002-015-0061-z

Ogah, E. O. (2013). Evaluating the Impact of New Rice for Africa (NERICA) in the Management of Rice Stem Borers. International Journal of Science, 1(5), 160-166. https://doi.org/10.5567/sciintl.2013.160.166

Ogah, E. O., Echezona, B. C., \& Umeh, E. D. N. (2005). Effects of N-fertilization and spacing on African Rice Gall midge, Orseolia oryzivora Harris and Gagne in a Sub-humid area of Southern Nigeria. Journal of Agriculture, Food and Environmental Extension, 4(2), 15-18. Retrieved from http://www.agroscience journal.com/public/agro4o2-3.pdf

Pathak, M., \& Khan, Z. R. (1994). Insect pests of rice (pp. 5-16). International Centre of Insect Physiology and Ecology, International Rice Research Institute, Manila Philippines.

Rhoades, R. E., \& Booth, R. H. (1982). Farmer back to farmer: A model for generating acceptable agricultural technology. Journal of Agricultural Administration, 11, 127-137. https://doi.org/10.1016/0309-586X(82) 90056-5

Rural Livelihood Development. (2009). Improving rice profitability through increased profitability and better marketing focusing on Tanzania's central corridor.ailable (p. 37). Rice Assessment and Draft Sector Strategy of Tanzania. Retrieved from http:/www.rldp.org/downloads/rice_strategy.pdf

Sarwar, M. (2012). Effects of potassium fertilization on population build-up of rice stem borers (lepidopteron pests) and rice (Oryza sativa L.) yield. Journal of Cerial Oil Seeds, 3(1), 6. https://dx.doi/10.5897/ JCO11.041 
Sarwar, M., Ahmad, N., \& Tofique, M. (2011). Impact of Soil Potassium on Population Buildup of Aphid (Homoptera: Aphididae) and Crop Yield in Canola (Brassica napus L.) Field. Pakistan Journal of Zoology, 43(1), 15-19. Retrieved from http://www.zsp.com.pk/15-19\%20(3)\%20PJZ-3-09.pdf

Saunders, M., Lewis, P., \& Thornhill, D. (2007). Research Methods for Business Students (4th ed., p. 226). Prentice Hall, London.

Sheikh, F. A., Khan, M. N., Sofi, P. A., Dar, Z. A., Sofi, N. R., Javaid, A., \& Bhat, M. A. (2017). Farmers' Preference Ranking in Bush type of Common Bean (Phaseolus vulgaris L.) in Kashmir-Participatory Varietal Selection. International Journal of Pure Applied Bioscience, 5, 712-719. http://doi.org/10.18782/ 23207051.2573

Sigsgaard, L. (2000). Early season natural biological control of insect pests in rice by spiders and some factors in the management of the cropping system that may affect this control. Proc. 19th European Colloquium of Arachnology, Arhus (pp. 57-64).

Singh, P., Singh, R., Dhaka, S. S., Kumar, D., Kumar, H., \& Kumar, N. (2015). Bioefficacy of insecticides and bio-pesticides against yellow stem borer, Scirpophaga incertulus (walk.) and their effect on spiders in rice crop. South Asian Journal of Food and Technology Environment, 1(2), 179-183. Retrieved from http://www.sweft.in/download/volumes1:issue_2_Paper\%2014.pdf

SPSS Inc. (Statistical Package for Social Sciences). (2005). SPSS users guide (Version 15). Chicago (IL): SPSS Inc.

Srivastava, S. K., Salim, M., Rehman, A., Singh, A., Garg, D. K., Prasad, C. S., ... Kamal, N. Q. (2000). Stem Borer of Rice-Wheat Cropping System: Status, diagnosis, biology and management. Rice-Wheat Consortium Bulletin Series (p. 112). Rice-Wheat Consortium for the Indo-Gangetic Plains, New Delhi.

Tefera, T. (2004). Farmers' perceptions of sorghum stem-borer and farm management practices in Eastern Ethiopia. International Journal of Pest Management, 50(1), 35-40. https://doi.org/10.1080/0967087031000 1626356

Wonnacott, T. H., \& Wonnacott, R. J. (1990). Introductory Statistics for Business and Economics (4th ed.). John Wiley and Sons, USA.

\section{Appendix}

Appendix 1. Questionnaire Field Survey for Rice Stems Borers

\section{SECTION 1: METADATA}

\section{Introductory and consent statement:}

"Dear Sir/Madam, I work for the +++++++. We are conducting a survey to study farmers' rice insect pests' knowledge and their management practices in your village. Your response to these questions would remain anonymous. Taking part in this study is voluntary. If you choose not to take part, you have the right not to participate and there will be no consequences. Do you and your family consent to provide information? $1=$ yes, 0 = No. Thank you for your kind co-operation".

\begin{tabular}{|l|l|}
\hline & NAME \\
\hline ENUMERATOR ID & \\
\hline NAME OF WARD & \\
\hline NAME OF VILLAGE & \\
\hline
\end{tabular}




\section{SECTION 2: LOCATING HOUSEHOLD AND OBTAINING CONSENT}

\begin{tabular}{|c|c|c|c|}
\hline No. & QUESTIONS & CODES/RESPONSES & GO TO \\
\hline \multicolumn{4}{|c|}{$\begin{array}{l}\text { [INTERVIEWER: YOUR FIRST JOB IS TO LOCATE THE HOUSEHOLD AND THE FARMER THAT WAS } \\
\text { IDENTIFIED IN THE LIST TO BE INTERVIEWED. IF YOU CANNOT FIND THE HOUSEHOLD OR TH } \\
\text { FARMER IS NO LONGER IN THE VILLAGE, THESE QUESTIONS WILL HELP TO DETERMINE WITH } \\
\text { WHOM (OR IF) THE INTERVIEW WILL BE CONDUCTED. }\end{array}$} \\
\hline 1 & $\begin{array}{l}\text { WERE YOU ABLE TO LOCATE } \\
\text { THE HOUSE? }\end{array}$ & 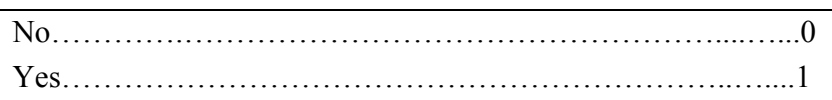 & $\begin{array}{l}>\text { Q6 } \\
>\text { Q2 }\end{array}$ \\
\hline 2 & $\begin{array}{l}\text { Please write down the correct } \\
\text { latitude of the housed. }\end{array}$ & [USE GPS DEVICE]: & \\
\hline 3 & $\begin{array}{l}\text { Please write down the correct } \\
\text { longitude of the house. }\end{array}$ & [USE GPS DEVICE]: & \\
\hline 4 & $\begin{array}{l}\text { DOES THE FARMER (HE/SHE) } \\
\text { CONSENT TO BEING } \\
\text { INTERVIEWED? }\end{array}$ & 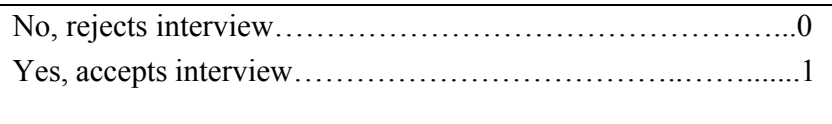 & $\begin{array}{l}>\text { STOP } \\
>\text { Q5 }\end{array}$ \\
\hline 5 & Name of farmer & (WRITE DOWN NAME): & \\
\hline
\end{tabular}

\section{SECTION 3: DEMOGRAPHIC INFORMATION}

\begin{tabular}{|c|c|c|c|}
\hline No & QUESTIONS & CODES/RESPONSES & GO TO \\
\hline \multicolumn{4}{|c|}{$\begin{array}{l}\text { [INTERVIEWER: SAY TO THE FARMER: I WOULD FIRST LIKE TO ASK YOU QUESTIONS ABOUT } \\
\text { YOURSELF AND YOUR FAMILY. }\end{array}$} \\
\hline 1 & What is your age? & Y_l_ & \\
\hline 2 & $\begin{array}{l}\text { Male or female? [MAY NOT } \\
\text { NEED TO ASK] }\end{array}$ & 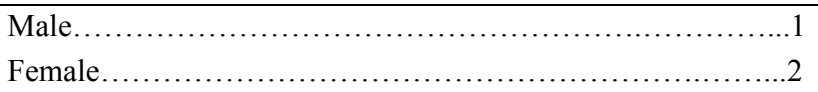 & \\
\hline 3 & $\begin{array}{l}\text { Has the farmer ever attended } \\
\text { school? }\end{array}$ & 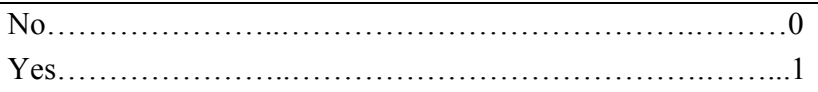 & $\begin{array}{l}>\text { Q5 } \\
>\text { Q4 }\end{array}$ \\
\hline 4 & What is your level of education & 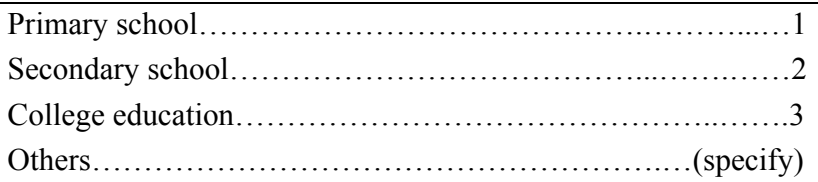 & \\
\hline & \multicolumn{2}{|c|}{ How many family members live in your house (live under same roof)? } & \\
\hline \multirow[t]{2}{*}{5} & ... Number of male members? & & \\
\hline & Their age? & 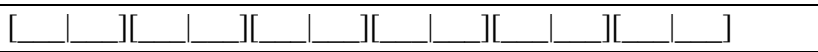 & \\
\hline \multirow[t]{2}{*}{6} & ... Number of female members? & [ & \\
\hline & Their age? & 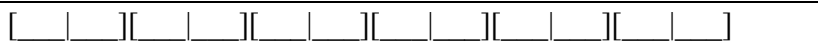 & \\
\hline 7 & $\begin{array}{l}\text { How many of these family members } \\
\text { work or are able to work? (Q12 } \\
\text { CANNOT BE GREATER THAN } \\
\text { Q12 AND Q13) }\end{array}$ & {[} & \\
\hline 8 & What is your marital status & 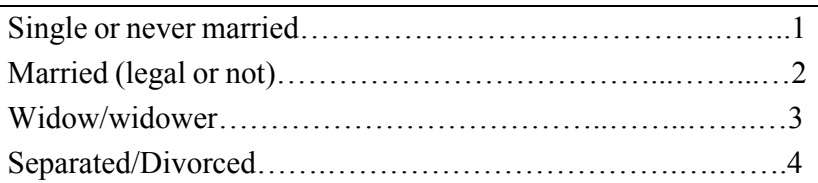 & \\
\hline
\end{tabular}




\section{SECTION 4: RICE PRODUCTION}

\begin{tabular}{|c|c|c|c|}
\hline No & QUESTIONS & CODES/RESPONSES & GO TO \\
\hline \multicolumn{4}{|c|}{$\begin{array}{l}\text { [INTERVIEWER: SAY TO THE FARMER: NOW I WOULD LIKE TO ASK YOU SOME QUESTIONS ABOUT } \\
\text { THE RICE YOU PRODUCED }\end{array}$} \\
\hline 1 & $\begin{array}{l}\text { How many acres of rice do you } \\
\text { own? }\end{array}$ & 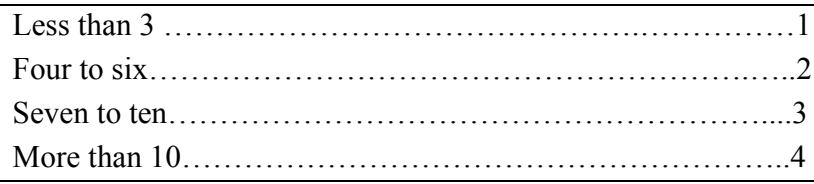 & \\
\hline 2 & $\begin{array}{l}\text { During the past } 12 \text { months what was } \\
\text { the total value of the Rice you } \\
\text { harvested? }\end{array}$ & 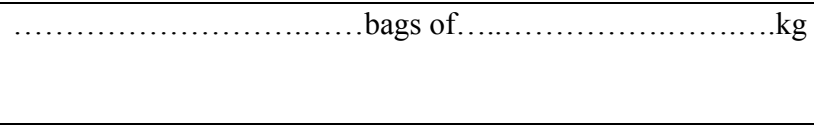 & \\
\hline 3 & $\begin{array}{l}\text { What proportion of your Rice } \\
\text { production do you consume in your } \\
\text { household? }\end{array}$ & 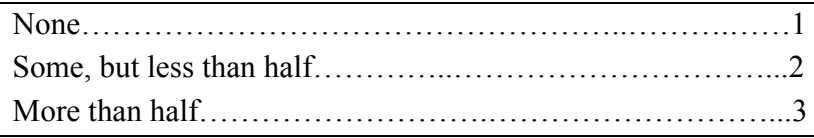 & \\
\hline 4 & $\begin{array}{l}\text { What proportion of your family's } \\
\text { income is from selling Rice? }\end{array}$ & 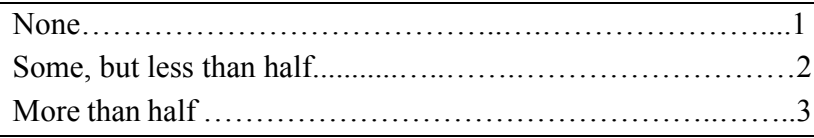 & \\
\hline
\end{tabular}

\section{SECTION 5: PESTS and PEST MANAGEMENT OF RICE CROP}

\begin{tabular}{|c|c|c|c|}
\hline No & QUESTIONS & CODES/RESPONSES & GO TO \\
\hline \multicolumn{4}{|c|}{$\begin{array}{l}\text { INTERVIEWER: SAY TO THE FARMER: NOW I WOULD LIKE TO ASK YOU SOME QUESTIONS ABOUT } \\
\text { YOUR RICE PEST MANAGEMENT LAST YEAR. }\end{array}$} \\
\hline 1 & $\begin{array}{l}\text { DID YOU GROW RICE LAST } \\
\text { YEAR? }\end{array}$ & 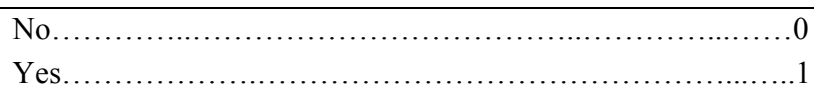 & \\
\hline 2. & $\begin{array}{l}\text { What were the main constraints } \\
\text { you faced in rice production (start } \\
\text { from the most to the least } \\
\text { constraint) }\end{array}$ & 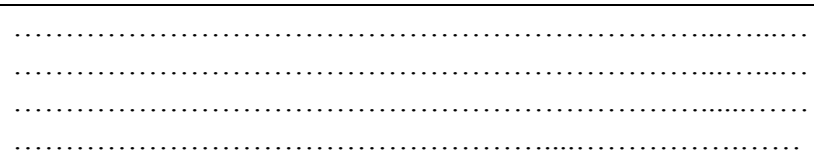 & \\
\hline $\mathrm{a}$ & $\begin{array}{l}\text { How severe were rice insect pests } \\
\text { last year? }\end{array}$ & 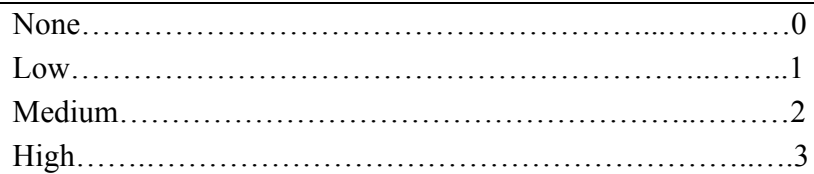 & \\
\hline $\mathrm{b}$ & $\begin{array}{l}\text { What was your worst insect pest last } \\
\text { year? }\end{array}$ & Specify: & \\
\hline $\mathrm{c}$ & $\begin{array}{l}\text { How severe were your rice insect } \\
\text { pest last year? }\end{array}$ & 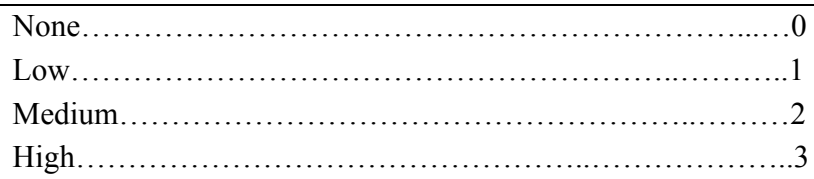 & \\
\hline $\mathrm{d}$ & $\begin{array}{l}\text { What are the major insect pests } \\
\text { affecting rice? }\end{array}$ & 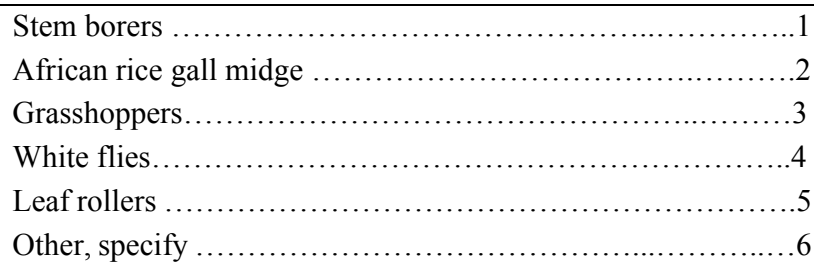 & \\
\hline $\mathrm{e}$ & $\begin{array}{l}\text { What practices, if any, did your } \\
\text { household use to control these insect } \\
\text { pests? } \\
\text { (CIRCLE ALL THAT APPLY) }\end{array}$ & 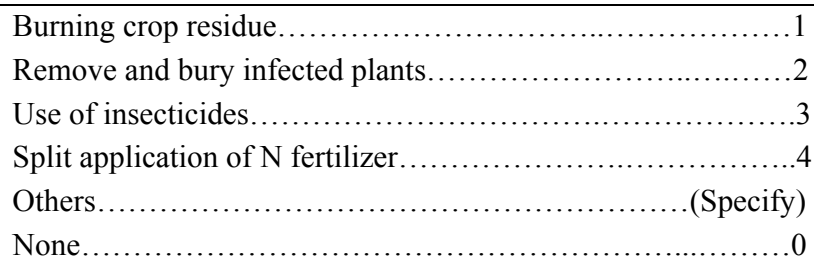 & \\
\hline $\mathrm{f}$ & $\begin{array}{l}\text { List the names of all chemical inputs } \\
\text { which was used in management of } \\
\text { rice insect pests }\end{array}$ & & \\
\hline
\end{tabular}




\section{SECTION 6: FARMERS' PERCEPTION ON RICE STEM BORER}

(a) Do you know the rice stem borer? (1) Yes, (2) No

(b) If yes, what is its local name?

(c) Has rice stem borer ever affected your farm? (1) Yes, (2) No (If yes, answer the following questions)

(d) What are the symptoms? (1) Dead heart, (2) White head, (3) Dead heart and white head

(e) What insect pest is more destructive in rice production? (1) Stem borer, (2) Others (specify), (3) None

(f) Have you ever realized rice stem borer occurrences in other farms? (1) Yes, (2) No

(g) If yes indicate the month, year and distance of the farm from your farm.

\begin{tabular}{|l|l|l|}
\hline Month & Year & Distance from your farm (see code sheet) \\
\hline & & \\
\hline & & \\
\hline & & \\
\hline
\end{tabular}

h) Does the borers affect the rice crop in your farm throughout the growing season? (Please tick as appropriate)

(1) Yes

(2) No

(i) If No, Indicate which month(s) of the year the disease is prevalent

\begin{tabular}{|l|l|l|l|l|l|l|l|l|l|l|l|l|}
\hline \multirow{2}{*}{ Month } & Jan & Feb & Mar & Apr & May & Jun & Jul & Aug & Sept & Oct & Nov & Dec \\
\cline { 2 - 10 } & & & & & & & & & & & & \\
\hline
\end{tabular}

\section{Copyrights}

Copyright for this article is retained by the author(s), with first publication rights granted to the journal.

This is an open-access article distributed under the terms and conditions of the Creative Commons Attribution license (http://creativecommons.org/licenses/by/4.0/). 